\title{
Pemberdayaan Perempuan Melalui Usaha Tenun di Nagari Tanjung Bonai Kecamatan Lintau Buo Utara
}

\author{
Gusni Yulia, Fatmariza \\ Prodi Pendidikan Pancasila dan Kewarganegaraan \\ FIS Universitas Negeri Padang \\ E-mail: fatmariza.unp@gmail.com
}

\section{ABSTRAK}

Penelitian ini bertujuan untuk memberikan gambaran tentang proses pemberdayaan, hasil dari program pemberdayaan dan dampak program pemberdayaan perempuan melalui usaha tenun di nagari Tanjung Bonai Kecamatan Lintau Buo Utara. Penelitian ini merupakan penelitian kualitatif, informan penelitian ini adalah ibu-ibu pengrajin tenun. Teknik pengumpulan data dilakukan melalui observasi, wawancara, dan dokumentasi. Data yang terkumpul di analisis dengan cara reduksi data, penyajian data dan penarikan kesimpulan dan verifikasi data menggunakan teknik triangulasi sumber. Hasil penelitian mengungkapkan bahwa persiapan program keterampilan bertenun melalui sosialisasi program rumah ke rumah maupun pertemuan PKK, pendaftaran anggota kelompok dan penentuan waktu serta tempat pelaksanaan bertenun di sanggar tenun Batenggang Banang sahalai atau dilakukan dirumah penenun. Sistem kerja dilakukan secara individu dengan tanggungjawab menenun kain menggunakan sarana yang disediakan. Program pemberdayaan perempuan berimplikasi pada berubahnya aktivitas pengrajin sebagai ibu rumah tangga dengan aktivitas sampingan bertenun sehingga dapat meningkatan pendapatan keluarga.

Kata Kunci: evaluasi kebijakan, Bantuan Pangan Non Tunai, penanggulangan kemiskinan

\section{ABSTRACT}

The aim of this research was to provide an overview of the empowerment process, the results of the empowerment program, and the impact of the women's empowerment program through weaving businesses in the nagariTanjungBonai, North LintauBuo District.This research is a qualitative research, the subjects of this research are the women or mothers of weaving craftsmen. Data collection techniques are done through observation, interviews, and documentation. The data collected was analyzed descriptively qualitatively, that is, the qualitative description of data obtained from the field using source triangulation techniques. Data analysis was performed by data reduction, data presentation and conclusion drawing. The results of the study showed that preparation of the weaving skills program through program socialization to women going to homes and PKK meetings, group member registration and determining the time and place for weaving. Weaving is carried out in the Batenggang weaving studio in Banangsahalai and may also be brought home. The work system is carried out individually, each individual has a duty to make woven fabric crafts using the facilities provided. The results of the women's empowerment program 
include the changes of housewives' activities initially at home taking care of the family, after this program the activities of housewives have changed, namely having weaving skills activities, and educating to be independent. The impact of implementation includes improving social status, increasing family economic income.

Keywords: empowering, women, weaving skills

\section{PENDAHULUAN}

Kebijakan pemberdayaan perempuan dikeluarkan oleh Pemerintah Kabupaten Tanah Datar dalam rangka pengurangan angka kemiskinan dan pengangguran. $\mathrm{Hal}$ ini ditenggarai dengan adanya jumlah penduduk di Kabupaten Tanah Datar tahun 2018 adalah 347.407 jiwa dengan jumlah perempuan 176.515 jiwa dengan persentase kemiskinan adalah 5,56\%. Kebijakan yang dilakukan adalah dengan memberikan bantuan dana melalui Program Nasional Pemberdayaan Masyarakat (PNPM) dan dana hibah untuk dikembangkan oleh masyarakat melalui keterampilan yang dimiliki oleh masyarakat. Program tersebut salah satunya difokuskan pada pemberdayaaan perempuan melalui Dekranasda (Dewan Kerajinan Nasional Daerah) dengan memberdayakan para pengrajin di sentra tenun yaitu tenun Pandai Sikek dan tenun Lintau.

Program ini telah dilakukan pada Kecamatan Lintau Buo Utara dengan 1 (satu) dari 5 (lima) kelompok kerajinan tenun yang ada menerima bantuan dari pemerintah. Kelompok yang menerima yakni kelompok tenun Batenggang di Banang Sahalai. Kelompok tenun ini berdiri pada tahun 2015 di Jorong
Tanjung Modang yang sering disebut dengan Kampung Tenun dengan 37 orang pengrajin. Pengrajin tenun dikelompok ini adalah ibu rumahtangga yang sebelumnya memiliki pekerjaan sampingan buruh tani yang menerima upah harian.

Setelah adanya bantuan dari pemerintah utuk kegiatan keterampilan bertenun, perempuan di jorong ini umumnya lebih memilih untuk mengikuti kegiatan bertenun yang dibina oleh Dekranasda. Sanggar tenun ini mendapat bantuan dana dari Dekranasda berupa dana hibah dari pemerintah Tanah datar dan bantuan dari bank BRI.

Dana hibah yang diberikan adalah sebesar 104 juta rupiah. Dana ini merupakan modal awal yang digunakan untuk membangun sanggar Batenggang di Banang Sahalai dan sisa dari pembangunan digunakan untuk membeli alat tenun tradisional. Dana dari bank BRI ini digunakan untuk membeli alat tenun yang modern yaitu Alat Tenun Bukan Mesin (ATBM) dan perlengkapan lainnya. Pembinaan yang dilakukan seperti cara menggunakan alat-alat tenun dan menghasilkan tenun yang halus. Dari tahun 2015 hingga tahun 2019 kelompok tenun Batenggang di Banang Sahalai sudah menghasilkan 
kain songket dan baju. Dalam satu bulan pengrajin bisa menghasilkan 17 sampai 40 hasil tenun. Pengrajin tenun sudah memasarkan dan mengikuti beberapa pameran bahkan sampai tingkat nasional. Harga untuk sehelai kain songket mencapai satu hingga 2,5 juta rupiah. Dalam rentang waktu 4 tahun pengrajin yang sebelumnya berjumlah 37 orang sekarang hanya tinggal 20 orang. Hal ini disebabkan karena di Kecamatan Lintau Buo dan Lintau Buo Utara baru meresmikan sebuah sentra tenun untuk pelatihan menenun yang di kelola oleh UPT dan Yayasan Kriya Minangkabau.

Program pemberdayaan perempuan dalam kehidupan keluarga mampu menjadi pintu masuk perbaikan kesejahteraan keluarga. Berkaitan dengan perbaikan kesejahteraan keluarga maka telah menuntut perempuan untuk dapat menopang ketahanan ekonomi keluarga. Kondisi demikian merupakan dorongan yang kuat bagi perempuan untuk berkerja dalam menambah penghasilan. Perempuan perlu diberikan suatu pelatihan, pendidikan, dan pemberdayaan, agar memiliki kemmpuan untuk hidup layak dan bisa membantu suami untuk memnuhi kebutuhan seharihari (Murniati, 2004).

Seperti halnya program pemberdayaan perempuan yang telah dilakukan di Nagari Tanjung Bonai, pemerintahan Kabupaten Tanah Datar memberikan bantuan berupa dana hibah kepada sanggar tenun Batenggang di Banang Sahalai di Nagari Tanjung Bonai dengan memanfaatkan sumber daya manusia yang ada. Tujuannya agar perempuan disana memiliki suatu kemampuan atau keahlian. Berdasarkan penelitian sebelumnya, menurut (Rizka,2015) menjelaskan model pemberdayaan telah membawa dampak sebagai berikut. Pertama, meningkatnya kesadaran perempuan dalam berkomunikasi dengan anggota masayarakat diluar system sosialnya. Kedua, meningkatnya partisipasi perempuan dalam kegiatan pembelajaran yang diselenggarakan oleh agen perubahan masyarakat desa. Ketiga, meningkatnya pengetahuan dan keterampilan perempuan dalam bidang perencanaan, pengorganisasian, pelaksanaan, penilaian dan pengembangan kegiatan pembelajaran dilingkungan mereka sendiri. Keempat, meningkatnya pengetahuan, keterampilan, sikap kreativitas dan aspirasi perempuan, khususnya keterampilan produktif. Kelima, tumbuhnya usaha-usaha produktif berbasis sosial budaya dalam bentuk industry rumah tangga yang diusahakan oleh perempuan dan hasilnya dapat dipasarkan. Keenam, tumbuhnya sikap kemandirian usaha atau sikap mental kewiraswastaan dikalangan perempuan. Ketujuh, tumbuhnya pola hidup hemat dan ada perencanaan keuangan keluarga.

Menurut Nugroho (2008) tujuan dari program permberdayaan perempuan antara lain: 1, Meningkatkan kemampuan kaum perempuan untuk berpartisipasi aktif (subjek) agar tidak sekedar menjadi objek pembangunan seperti yang terjadi selama ini. 2, meningkatkan kemampuan kaum perempuan dalam kepemimpinan, meningkatkan posisi tawar-menawar dan keterlibatan dalam setiap pembangunan baik sebagai perencana, pelaksana, 
Journal of Civic Education (ISSN: 2622-237X)

Volume 4 No. 12021

maupun melakukan monitoring dan evaluasi kegiatan. 3, meningkatkan kemampuan kaum perempuan dalam mengelola usaha skala rumah tangga, industri kecil maupun industri besar untuk menunjang peningkatan kebutuhan rumah tangga, maupun untuk membuka peluang kerja produktif dan mandiri. 4, meningkatkan peran dan fungsi organisasi perempuan ditingkat lokal sebagai wadah pemberdayaan kaum perempuan agar terlibat secara aktif dalam program pembangunan pada wilayah tempat tinggalnya. Menurut Parsons yang dikutip oleh Suharto, pemberdayaan yaitu sebuah proses dimana orang menjadi cukup berpartisipasi dalam berbagai pengontrolan yang mempengaruhi kejadian-kejadian serta lembagalembaga kehidupannya.

Pemberdayaan menekankan agar setiap orang memperoleh keterampilan-keterampilan,

pengetahuan dan kekuasaan yang cukup untuk mempengaruhi kehidupan orang lain. Sedangkan pendapat Ife yang dikutip oleh (Suharto, 2005) menyatakan bahwa pemberdayaan bertujuan untuk meningkatkan kekuasaan setiap orang yang lemah atau tidak beruntung. Pengertian lain, pemberdayaan atau pengembangan sumber daya manusia adalah upaya memperluas pilihan bagi masyarakat, memberikan kemampuan pada masyarakat untuk bisa memikir lebih baik untuk jangka panjang. Sehingga ini dapat diartikan masyarakat diberdayakan untuk melihat serta memilih sesuatu yang bermanfaat bagi dirinya. Mereka belajar untuk menyederhanakan sesuatu yang sulit mereka pahami, dengan memakai logika mereka sendiri, sehingga dapat dikatakan bahwa masyarakat yang berdaya adalah yang dapat memilih dan mempunyai kesempatan untuk mengadakan setiap pilihan.

\section{METODE PENELITIAN}

Penelitian ini menggunakan metode penelitian kualitatif untuk mengumpulkan data pendapat dan gambar dengan cara observasi, wawancara dan dokumentasi. Pemilihan informasi ditentukan secara purposive sampling yaitu penemuan informasi dengan adanya pertimbangan atau ciri - ciri tertentu yang sesuai dengan tujuan yang akan dihasilkan. Dalam pengambilan atau pengumpulan data penulis menggunakan teknik wawancara, observasi, dan dokumentasi. Jenis datanya yaitu data primer dan data skunder.

Teknik keabsahan data menggunakan teknik triangulasi sumber. Analisa data yang digunakan yaitu reduksi data, yaitu peneliti harus merangkum, memilih hal-hal pokok, memfokuskan pada hal-hal yang penting, dicari tema dan polanya dan membuang yang tidak perlu. Dengan demikian, data yang telah direduksi memberikan gambaran yang lebih jelas, mempermudah peneliti untuk melakukan pengumpulan data selanjutnya. Penyaji data, dengan menyajikan data, maka akan memudahkan untuk memahami apa yang terjadi, merencanakan kerja selanjutnya berdasarkan apa yang telah dipahami tersebut. Pengambilan kesimpulan 
langkah ketiga dalam analisis data kualitatif adalah penarikan kesimpulan. Kesimpulan awal masih bersifat sementara, dan akan berubah bila tidak ditemukan bukti-bukti yang kuat yang mendukung pada tahap pengumpulan data berikutnya (Sugiyono, 2008).

\section{HASIL DAN PEMBAHASAN}

Pelaksanaan Program Pemberdayaan Perempuan Melalui Usaha Tenun di Nagari Tanjung Bonai

Kegiatan bertenun di Sanggar Batenggang Banang Sahalai dilakukan sebagai upaya untuk melakukan pemberdayaan kaum perempuan. Fenomena yang ada sebelum adanya kelompok sanggar seperti aktivitas para ibu rumah tangga yang hanya mengurus keluarga menjadikan ibuibu rumah tangga dan menjadi bergantung pada suami. Pekerjaan suami yang mayoritas sebagai petani, kuli bangunan, dan sopir membuat ibu-ibu hanya pasrah pada keadaan terkait pendapatan suami yang diperoleh yang kurang mencukupi untuk kebutuhan sehari-hari. Atas dasar itulah, maka diperlukan kepudulian dalam menggali potensi dan ketrampilan masyarakat setempat khususnya ibu rumah tangga agar mendapatkan kehidupan yang layak, mandiri dan dapat meningkatkan pendapatan keluarga. Salah satunya melalui program pemberdayaan bertenun. Melalui pemberdayaan ini diharapkan agar perempuan di sanggar atau kelompok ini dapat merubah pola pikir untuk lebih mandiri, giat, tekun, dan dapat meningkatkan perekonomian keluarga.

Dari hasil penelitian di lapangan dapat dikemukakan bahwa persiapan program pemberdayaan di kelompok tenun Batenggang di Banang Sahalai dilakukan dengan melakukan sosialisasi ke masyarakat. Sosialisasi dilakukan sebelum kelompok tenun ini dibentuk. Agar masyarakat mengetahui akan adanya kegiatan bertenun maka para ibu-ibu yang sebelumnya sudah pernah mengikuti kegiatan bertenun memberikan pengarahan dan sosialisasi kepada ibu-ibu melalui kegiatan PKK atau kegiatan lainnya di sekitar wilayah tersebut dan didukung oleh pemerintah setempat dengan dibangun sebuah sanggar tenun.

Awalnya kegiatan ini hanya diikuti 7 orang dengan alat seadanya. Dengan sosialisasi ke masyarakat maka masyarakat melakukan kegiatan swadya untuk mengembangkan sanggar tenun ini; Setelah dilakukan sosialisasi maka dilakukan pendataan kepada masyarakat yang berminat dan tertarik untuk bergabung. Pendataan dilakukan oleh ketua sanggar dan dibantu oleh rekannya karena sebelumnya hanya mereka berdua yang sudah pernah mengikuti kegiatan bertenun dan ide untuk membentuk kelompok ini dari ketua sanggar tesebut; Selanjutnya pelatihan bertenun dilakukan setelah namanama dari anggota tenun tersebut sudah terdaftar dan pemerintahan setempat yang ikut memajukan sanggar ini meminta bantuan dari pemerintah kabupaten di bawah Dekranasda dan Koperindag. Masyarakat yang baru bergabung di kelompok tenun Batenggang di Banang Sahalai diberikan pelatihan tentang teknik bertenun oleh Dekranasda dan Koperindag.
Fungsi dari kegiatan ini diharapkan dapat mengasah dan 
meningkatkan kemampuan bertenun pada warga atau masyarakat yang bergabung. Subyek dalam penelitian ini adalah ibu-ibu yang tergabung dalam kelompok tenun Batenggang. Penentuan subyek dalam penelitian ini didasarkan pada kekhususan atau memiliki kemampuan dalam menjawab permasalahan yang ada. Adapun karakteristik subyek penelitian berdasarkan nama, alamat, usia dan tingkat pendidikan. Pelaksanaan bertenun dilaksanakan mulai pukul 09.00 - 16.00 WIB. Sistem kerja dilakukan secara perorangan. Ibu-ibu pengrajin juga diperkenankan membawa kerajinan tenunnya untuk di bawa pulang dan dikerjakan di rumah karena di rumah beberapa anggota yang masih aktif sudah memiliki alat tenun.

Para pengrajin tenun dapat memasarkan hasil tenunnya terlebih dahulu dan setelah itu baru mendapatkan upah dari hasil yang di jual. Dalam satu bulan para pengrajin dapat menyelesaikan hasil tenun 1740 helai kain tenun. Selembar kain tenun dapat terjual Rp.1.000.000 - Rp. 2.500.000. Kegiatan pemberdayaan perempuan pada kelompok tenun Batenggang terbuka untuk ibu-ibu dan anak perempuan yang putus sekolah atau yang tidak memiliki pekerjaan, dengan syarat mereka memiliki kemampuan, mencintai tenun dan memiliki komitmen untuk menambah perekonomian keluarga. Hasil penelitian dilapangan juga menunjukkan bahwa adanya kelompok tenun telah mendidik anggota kelompok untuk mandiri dan tidak bergantung sepenuhnya pada suami dalam memenuhi kebutuhan sehari-hari.
Adanya perubahan pola pikir dan cara pandang pada ibu rumah tangga dan perempuan di Jorong Tanjung Modang telah mendidik anggota kelompok untuk tekun, kreatif dan mengembangkan kemampuan yang dimiliki sesuai dengan bakat yang dimiliki. Aktivitas yang selama ini dilakukan seperti bersendau gurau dengan sesama tetangga, arisan dan perilaku serta sikap yang menyerah pada keadaan telah berubah menjadi kegiatan yang positif berupa keterampilan bertenun.

Sedangkan bagi kelompok, adanya program pengembangan tenun di Kabupaten Tanah Datar melalui kegiatan usaha kecil menengah (UKM) telah mendorong pengembangan ekonomi kerakyatan. Hal tersebut terlihat dari jumlah permintaan kain tenun melalui kelompok tenun Batenggang yang selalu meningkat setiap bulan baik yang dating dari dalam maupun luar daerah. Sehingga sanggar tenun Batenggang di Banang Sahalai juga semakin dikenal oleh masyarakat luas.

Jika dilihat dari tingkat pendapatan, maka ibu rumah tangga di Tanjung Modang, rata-rata memperoleh pendapatan antara Rp. 1.000.000,00- Rp. 2.000.000,00, akan tetapi besaran pendapatan antar anggota kelompok yang satu dengan anggota kelompok yang lain berbedabeda tergantung jumlah kain tenun yang berhasil diproduksi dan yang berhasil di jual.

Faktor Pendukung Pemberdayaan Perempuan Melalui Usaha Tenun Batenggang

Faktor pendukung dari pelaksanaan program pemberdayaan perempuan melalui kelompok tenun 
pada ibu rumah tangga dan perempuan di Nagari Tanjung Bonai antara lain:

a. Adanya dukungan dari suami kepada para ibu rumah tangga

Dukungan dari suami dan keluarga yang merupakan hal yang sangat dibutuhkan oleh ibu-ibu rumah tangga untuk melakukan kegiatan bertenun. Dengan adanya dukungan dari suami, ibu - ibu juga bersemangat untuk melakukan kegiatan bertenun. Ibu-ibu memiliki rasa kemandirian dengan tidak sepenuhnya bergantung pada suami dalam hal mencari pendapatan karena saat ini mereka sudah memiliki pendapatan sendiri. Ibu-ibu dapat memenuhi kebutuhan sehari-hari termasuk untuk membiayai anak anak sekolah.

b. Adanya dukungan dari masyarakat sekitar

Dukungan dari masyarakat, dukungan dari masyarakat juga hal yang sangat penting karena jika masyarkat sekitar tidak mendukung berdirnya kelompok maka kelompok tenun batenggang di banang sahalai tidak akan bisa berjalan dan tidak akan bisa melakukan kegiatan bertenun.

c. Adanya dukungan dari pemerintah KESIMPULAN

Pelaksanaan bertenun pada kelompok tenun Batenggang di Banang Sahalai dilakukan secara mandiri dimana setiap pengrajin berhak membuat hasil tenun secara sendiri dikerjakan di sanggar ataupun di bawa pulang. Hasil program pemberdayaan perempuan melalui kelompok tenun Batenggang antara lain berubahnya aktivitas para ibu rumah tangga yang awalnya hanya mengurus keluarga hingga saat ini mereka telah mempunyai aktivitas bertenun, serta menjadikan para ibu lebih mandiri dan tidak bergantung sepenuhnya pada suami. Dampak pelaksanaan program antara lain peningkatan perekonomian keluarga sehingga terpenuhi kebutuhan seharihari serta dapat membantu menyekolahkan anak-anaknya ke jenjang pendidikan yang lebih tinggi.

\section{DAFTAR PUSTAKA}

Fatmariza, F., Muchtar, H., Dewi, S. F., Irwan, I., Putra, I., Suasti, Y., \& Febriani, R. 2020. Peningkatan Pengetahuan dan Pemahaman Masyarakat Nagari Pasie Laweh tentang Kekerasan Terhadap Perempuan dan Anak melalui Penyuluhan. VIVABIO: Jurnal Pengabdian Multidisiplin, 2(1), 816.

Murniati, A. Nunuk P. 2004. Gentar Gender Perempuan Indonesia dalam Perspektif Agama, Budaya, dan Keuarga. Magelang: Indonesia Tera

Riant Nugroho D. 2008. Manajemen Pemberdayaan: Sebuah Pengantar dan Panduan untuk Pemberdayaan Masyarakat. Jakarta: Elex Media Komputindo Kelompok Gramedia

Sugiyono, 2008, Metode Penelitian Kuantitatif Dan Kualitatif Dan R \&D, Bandung, Alfabeta.

Suharto, Edi. 2005. Membangun masyarakat memberdayakan rakyat, Bandung: Refika Aditama

Wulandhani Rizka. 2015. Pemberdayaan perempuan melalui batik Tulis Lanting. Skripsi. Fakultas Ilmu Pendidikan UNY 